\title{
Penggunaan Media Alat Peraga Nasyid Sebagai Pembelajaran Inovatif Guna Memahami Konsep Agama Islam di SMA Negeri 1 Ambunten
}

\author{
Oleh : \\ L. QODRI SHIDDIQ \\ shidd39@gmail.com \\ Pengajar SMA Negeri 1 Ambunten
}

\begin{abstract}
Success of learning is determined by many factors, including the teacher's factor in carrying out the teaching and learning process because the teacher can directly affect Maintaining and improving intelligence and skills of the students solve the above problems and to achieve the education to the maximum the teacher's role is very important and teachers are expected to have a way of models of good teaching and being able to select appropriate learning models and in accordance with the concepts of subjects that will be presented

While the goal from the research is a to determine the significance of differences in learning acquisition between learning using songs that breathe Islam and learning without using songs that breathe Islam on the subject matter of Islamic religion on the subject of the journey of Ra. sulullah, $b$ to find out the significance of the difference in learning acquisition based on the learning styles of

SMA Negeri 1 students, know between the use of Islamic learning songs with the learning acquisition of students in SMA Negeri 1 ambunten.

From the analysis, it is found that there is a significant difference in learning acquisition between Islamic religious learning. the subject matter of the Prophet's journey by using Islamic-breathed songs to students of SMA Negeri 1 ambunten means that the use of songs with Islamic breaths to organize the learning environment can increase the acquisition of learning and learning will be meaningful and successful when learning or students are free from pressure and tension, songs breathing Islam that is played can determine the mood of the listener and the lover, the sound of relaxing Islamic breathing songs with the right rhythm can help release all forms of tension, There is a real interaction between the use of Islamic-inspired songs Learning with learning acquisition in SMA Negeri 1 students provides an indication that between learning Islamic songs and learning outcomes have a close relationship, Islamic-breathed songs and learning styles have a significant influence in increasing learning acquisition
\end{abstract}

For keywords using media, tools nasyid display, innovative learning.

\section{Pendahuluan}

Idealnya sistem pendidikan yang baik dan berkualitas apabila input (siswa) yang kurang memiliki ketrampilan, setelah diproses menjadi manusia yang mampu mengembangkan ketrampilannya dan kepribadiannya. Penyelenggaraan pendidikan nsional pada masa depan, 
pembangunan dan perbaikan sistem pendidikan seharusnya ditujukan pada aspek-aspek ; kurikulum, sarana prasarana pendidikan, klualitas tenaga kependidikan, menejemen pendidikan serta peran serta masyarakat.

Profesionalisasi tenaga kependidikan, terutama guru Agama Islam ternyata menuntut sejumlah persyaratan, antara lain memiliki kualifikasi pendidikan profesi yang memadai, memiliki kompetensi keilmuan sesuai dengan bidang yang ditekuni, berjiwa kreatif dan produktif, memiliki etos kerja yang tinggi, serta selalu mengembangkan diri (continous improvement), melalui organisasi profesi, internet, buku dan semacamnya. Dengan syarat ini, guru bukan lagi sebagai 'knowledge based' seperti yang sekarang ini dilakukan, tetapi lebih sebagai competency based, yang menekankan penguasaan konsep keilmuan secara optimal dan perekayasaan yang berdasarkan nilai-nilai etika dan moral. Sehingga kondisi pembelajaran di dalam kelas terjadi dua arah antara guru dan siswa.

Dengan profesionalisme, fungsi guru Agama Islam masa depan tidak lagi sebagai pengajar (teacher), melainkan sebagai pembimbing (conselor), atau sebagai pelatih (trainercoach), atau sebagai menejer (learning manager). Sebagai conselor, guru Agama Islam sekaligus sebagai sahabat siswa, sebagai anutan dan tauladan dalam kepribadian, sehingga terjalin simpati dan keakraban antar siswa dan guru yang tidak meninggalkan rasa hormat dan penghargannya. Murid dapat belajar dari perilaku guru tanpa harusa guru memerintahkan murid untuk mencontohnya. Interaksi ini akan tercapai apabila guru profesional mampu menggunakan metode pembelajaran yang tepat dan dapat menyampaikan pesan yang berkesan dan menyenangkan sehingga mengembangkan potensi masing-masing siswa. Sebagai pelatih, untuk bekerja keras, untuk mencapai prestasi yang setinggi-tingginya, serta membantu siswa untuk menghargai nilai belajar dan pengetahuan.

Telah diketahui oleh banyak orang, bahwa ternyata potensi yang dimiliki oleh otak setiap orang sungguh sangat luar biasa. Namun sangat disayangkan, bila potensi yang besar tersebut tidak bisa dimanfaatkan secara penuh (maksimal) oleh manusia. Konon orang secerdas Einstein saja baru bisa memanfaatkan potensi otaknya sebesar 20\%. Lebih disayangkan lagi bahwa banyak diantara kita (guru Agama Islam ) yang tidak mengerti dan tidak mengetahui bagaimana memanfaatkan dan memotivasi potensi yang terdapat dalam otak tersebut. Akibatnya potensi yang terpendam tersebut tidak dapat muncul dan tidak memiliki arti apa-apa. 
Parahnya, potensi otak tidak termotivasi, melainkan malah semakin terpendam dalam, dan terkait semakin rapat, sehingga potensi tidak mengaktual.

Metode pembelajaran dan suasana pengajaran yang digunakan oleh guru Agama Islam di sekolah-sekolah kebanyakan tidak membangun motivasi potensi otak, melainkan menghambat perkembangan potensi otak. Siswa memasuki ruang belajar bukan karena keterkaitan tetapi lebih dikarenakan keterkaitan peraturan dan jadwal yang ditetapkan. Suasana belajar yang diciptakan justru membuat siswa cepat merasa jenuh dan bosan. Peserta didik dipaksa mendengarkan dan menerima semua informasi dari guru dan harus menaati seluruh peraturan yang ditetapkan oleh sekolah. Tidak ada waktu dan kesempatan bagi siswa untuk mengungkapkan kreativitasnya dan mengembangkan pola berfikirnya sendiri. Bagi kebanyakan guru, semua siswa dianggap sama dalam segala hal. Pendekatan dan metode pembelajaran yang digunakan tidak ada variasi, dari hari ke hari selalu tetap. Karena guru berpandangan bahwa semua siswa adalah identik (sama), seragam seperti warna baju yang dikenakan, warna celana seragam dipakai, sepatu, bahkan buku yang digunakan. Semuanya serba seragam. Padahala sesungguhnya potensi siswa tidaklah sama dan seragam. Gaya belajar mereka, kemampuan mereka, bakat, dan bahkan psikososial mereka cukup bervariasi.

Budaya pembelajaran yang seperti begini pada gilirannya akan membentuk generasi pasif yang tidak memiliki keberanian berpendapat, lemah penalaran dan memiliki ketergantungan terhadap orang lain. mental seperti ini memiliki korelasi signifikan dengan budaya dan mental masyarakat secara luas. Yaitu mental masyarakat yang tidak mampu berfikir mandiri, lahir gaya pemimpin "mohon petunjuk".

Belajar akan berhasil manakala didukung penciptaan suasana dan lingkungan belajar yang menyenangkan. Siswa akan menikmati belajarnya dalam ruang belajar yang nyaman, sejuk dan menyenangkan. Dengan memanfaatkan pengaruh nasyid misalnya untuk menata mental dan emosional spiritual Islami bagi siswa SMA Negeri 1 Ambunten untuk belajar.

Sampai saat ini, salah satu indikator, untuk pendidikan Agama Islam, yaitu Nilai Akhir Semester Sebagai ilustrasi, persentasi kualifikasi mutu SMA pada tahun 2019 menunjukkan angka 9\% masuk kategori sedang (5,5 - 6,5), dan 62,1\% masuk kategori kurang atau kurang sekali (kurang dari 5,5). Hal ini juga terlihat dalam Human Development Index (HDI) yang dipublikasikan oleh UNDP, yang menempatkan bangsa kita berada pada urutan ke-109 dari 173 negara di dunia. (Sii, $2001: 71$ ). 
Demikian halnya siswa SMA Negeri 1 Ambunten, perolehan Nilai Ujian Semester ratarata untuk beberapa tahun terakhir ini tidak mengalami perubahan yang berarti. Kiranya beberapa terobosan baru perlu dicari. Kembali kepada profesionalisme guru Agama Islam , dan kreatifitas guru Agama Islam. Guru Agama Islam memegang peranan yang sangat penting untuk membangun minat belajar guna meningkatkan prestasi belajar Agama Islam bagi siswa SMA Negeri 1 Ambunten . Terdorong oleh harapan ini dan beberapa masalah sebagaimana tersebut di atas, maka dipandang perlu untuk mengadakan penelitian : Penggunaan Media Alat Peraga Nasyid Sebagai Pembelajaran Inovatif Guna Memahami Konsep Agama Islam di SMA Negeri 1 Ambunten.

Karena selama ini belum pernah dilakukan penelitian serupa yang dilakukan terhadap siswa SMA dalam mata pelajaran Agama Islam .

\section{Pembahasan}

\section{A. Persiapan Tindakan}

Pada observasi mempelajari Agama Islam pokok bahasan kisah perjalanan Rasulullah. Hal yang dilakukan guru, ketika akan memulai pelajaran adalah melakukan renungan singkat yang diakhiri dengan do'a dan pemberian salam.

Kegiatan membuka pelajaran, guru Agama Islam memulai dengan menugaskan siswa untuk menyimak sebuah cerita singkat yang diceritakan guru Agama Islam, dilanjutkan tanya jawab isi cerita.

Kegiata inti pelajaran, guru memulai dengan menugaskan siswa untuk menyimak soal cerita dalam kisah saat Rasululloh hijrah ke Mekah yang ditulis guru di papan tulis sesuai dengan cerita dalam kegiatan membuka pelajaran Agama Islam . Kemudian guru membahas cara menyelesaikan cerita dengan langkah-langkah penyelesaiannya. Setelah pembahasan berakhir, guru memberi kesempatan kepada siswa untuk bertanya.

Selanjutnya setelah guru melakukan kegiatan membahas menyelesaikan cerita kisah perjalanan Rasullulloh selama hijrah dan tanya jawab selesai, kegiatan akhir dari kegiatan ini adalah melaksanakan evaluasi. Soal yang telah disiapkan guru berupa LKS dibagikan kepada siswa secara perorangan. Hasil evaluasi ini dikumpulkan tanpa diperiksa terlebih dahulu. 
Kegiatan akhir atau kegiatan menutup pelajaran guru menugaskan pada siswa untuk menyelesaikan pekerjaan rumah yang telah disiapkan guru dengan benar. Kemudian guru mengajak siswa menyiapkan buku pelajaran selanjutnya, yaitu buku paket Agama Islam

Berdasarkan hasil observasi sebagaimana yang telah digambarkan di atas mengenai pelaksanaan pembelajaran Agama Islam siswa SMA Negeri 1 Ambunten, bila dilihat dari perincian waktu dapat diklasifikasikan pada tabel berikut.

Tabel

Rincian waktu pelaksanaan pembelajaran Agama Islam

\begin{tabular}{|c|l|r|c|}
\hline No & \multicolumn{1}{|c|}{ Jenis kegiatan } & Waktu & \multicolumn{1}{|c|}{$\begin{array}{c}\text { Persentase } \\
(\%)\end{array}$} \\
\hline 1 & Kegiatan Awal & 20 menit & 25.00 \\
\hline 2 & Kegiatan Inti & 20 menit & 25.00 \\
\hline & a. Pembahasan Kisah Rasul & 5 menit & 6.25 \\
\hline & b. Tanya jawab & 25 menit & 31.25 \\
\hline & c. Evaluasi & 10 menit & 12.50 \\
\hline 3 & Kegiatan akhir/penutup & 80 menit & 100 \\
\hline & & & \\
\hline
\end{tabular}

Data pada tabel di atas menunjukkan bahwa dalam kegiatan pembelajaran keseluruhan yang merupakan kegiatan guru mencapai separuh dari waktu kegiatan yaitu 50\%. Lebih dari seperempat waktu kegiatan didominasi siswa mencapai $31.25 \%$ dan sisanya yang merupakan kegiatan guru dan siswa mencapai $18.75 \%$.

Berdasarkan gambaran tersebut di atas, menunjukkan bahwa kegiatan pembelajaran Agama Islam pokok bahasan kisah perjalanan Rasulullah pada siswa SMA Negeri 1 Ambunten tidak sesuai dengan peranan penting pembelajaran Agama Islam, lebih-lebih kalau dikaitkan dengan hakikat pendidikan secara umum. Atas dasar inilah perlu dilaksanakan perbaikanperbaikan.

Tindakan awal yang dilakukan penulis untuk memperbaiki kualitas pembelajaran Agama Islam di SMA sasaran adalah dengan cara mengadakan refleksi terhadap pendekatan pembelajaran yang telah dilakukan penulis selama ini. Adapun tujuannya adalah selain untuk mengetahui kemampuan siswa terhadap penyelesaian soal cerita Agama Islam, juga untuk 
memberikan pemahaman kepada penulis pentingnya menentukan suatu pendekatan pembelajaran yang tepat dalam mencapai tujuan pembelajaran yang telah ditetapkan.

Dari hasil tindakan awal tersebut dapat disimpulkan bahwa ketidak berhasilan siswa dalam menyelesaikan cerita kisah rasul selain disebabkan karena kurangnya kemampuan siswa dalam memahami kata-kata yang terpakai dalam kalimat cerita kisah para Rasululloh, juga disebabkan oleh karena kurang tepatnya penggunaan pendekatan pembelajaran yang dilakukan penulis sebagai guru Agama Islam pada siswa SMA Negeri 1 Ambunten sehingga siswa tidak dapat mengoptimalkan kemampuannya dan mencapai kepuasan diri yang sepenuhnya dalam menyelesaikan tugas yang ia terima.

Atas dasar itulah, penulis merencanakan melaksanakan pendekatan melalui media nasyid (lagulagu bernafaskan Islami) sebagai solusi permasalahan tersebut di atas.

\section{B. Pelaksanaan Tindakan I}

\section{Perencanaan}

Ada dua kegiatan yang dilakukan dalam tahap perencanaan ini Pembentukan kelompok didasarkan kepada heterogenitas siswa, baik ditinjau dari jenis kelamin, prestasi akademik, maupun aktifitas siswa sehari-hari.

2. Pelaksanaan dan observasi kegiatan pembelajaran menggunakan nasyid (lagu-lagu bernafaskan Islami)

Kegiatan awal yang dilakukan guru dalam proses pembelajaran adalah melakukan pre tes. Sasaran yang ingin dicapai melalui pre tes ini, yakni 1) mengetahui tingkat kemampuan siswa terhadap materi yang akan dikerjakan dan 2) untuk mengetahui tingkat keberhasilan belajar siswa dalam bidang kognitif dengan menggunakan pendekatan menggunakan nasyid (lagu-lagu bernafaskan Islami). Adapun hasil pre tes baik secara individu maupun kelompok dapat dilihat pada tabel berikut ini.

\section{Tabel}

Nilai Tes Responden di siswa Pada Tahap I

\begin{tabular}{|c|c|c|c|c|c|c|}
\hline No & Nilai & No & Nilai & No & Nilai & Keterangan \\
\hline 1 & 6.4 & 12 & 4.5 & 23 & 6.5 & \multirow{2}{*}{ Batas lulus 7.0 } \\
\hline 2 & 7.5 & 13 & 7.5 & 24 & 4.5 & \\
\hline
\end{tabular}




\begin{tabular}{|c|c|c|c|c|c|}
\hline 3 & 5.5 & 14 & 5.0 & 25 & 6.0 \\
\hline 4 & 7.5 & 15 & 6.0 & 26 & 4.5 \\
\hline 5 & 6.5 & 16 & 6.0 & 27 & 5.0 \\
\hline 6 & 7.0 & 17 & 4.5 & 28 & 4.5 \\
\hline 7 & 3.5 & 18 & 3.5 & 29 & 5.5 \\
\hline 8 & 7.0 & 19 & 7.5 & 30 & 7.5 \\
\hline 9 & 4.5 & 20 & 6.5 & 31 & 7.5 \\
\hline 10 & 3.5 & 21 & 6.5 & 32 & 5.5 \\
\hline 11 & 4.0 & 22 & 6.5 & & \\
\hline
\end{tabular}

Dari tabel tersebut dapat disimpulkan bahwa ada 3 orang siswa atau kurang dari setengahnya $(11.5 \%)$ yang dinyatakan lulus, sedangkan sisanya dinyatakan tidak lulus dalam pre tes. Sedangkan nilai rata-rata kelas dari pre tes tersebut adalah 5.83.

Pada kegiatan inti, guru menyajikan soal cerita kisah Rasul dan menginformasikan langkah-langkah yang harus dilakukan siswa pada saat menyelesaikan cerita secara klasikal. Kemudian guru menugaskan siswa masuk dalam kelompok yang telah dibentuk untuk melaksanakan tugas menyelesaikan LKS yang dibagikan guru.

\section{Analisis, Refleksi, dan Revisi Pembelajaran}

Berdasarkan hasil pengamatan terhadap tindakan menunjukkan bahwa kegiatan pembelajaran dengan menggunakan menggunakan nasyid (lagu-lagu bernafaskan Islami) sesuai dengan yang diharapkan.

Pada kegiatan ini khususnya yang berhubungan dengan pengembangan aspek kerja sama, aspek kepemimpinan dan aspek pengembangan nilai-nilai demokrasi belum sesuai dengan harapan untuk aspek kerja sama, setiap siswa cenderung mementingkan pekerjaannya sendiri, hampir lebih dari setengahnya (68.5\%) tidak mau memberikan bantuan terhadap temannya. Perilaku tersebut kelihatan ketika temannya belum selesai mengerjakan tugasnya maka temannya yang lain dalam kelompok tersebut tidak membantunya, bahkan sebaliknya mereka malah menyuruh cepat-cepat menyelesaikannya. 


\section{Pelaksanaan Tindakan II}

\section{Perencanaan}

Pada tahap perencanaan, kegiatan yang dilakukan guru yaitu perumusan masalah berdasarkan hasil analisis dan refleksi penulis pada tindakan pertama. Adapun masalah yang akan diperhatikan oleh para siswa dalam tindakan kedua itu adalah :Coba kalian perhatikan dengan baik kata yang dicetak miring pada soal cerita kisah Rasul dan pahami maksudnya!

2. Pelaksanaan dan observasi kegiatan pembelajaran menggunakan nasyid (lagu-lagu bernafaskan Islami)

Pada tindakan kedua ini, kegiatan yang dilakukan guru dalam proses pembelajaran sama dengan kegiatan sebelumnya kecuali pre tes tidak dilaksanakan.

Pada kegiatan inti, guru menginformasikan kepada para siswa untuk memperhatikan kata-kata yang dicetak miring pada LKS dan mengingatkan kembali langkah-langkah yang harus dilakukan siswa saat menyelesaikan soal cerita dengan mengumandangkan nasyid (lagu-lagu bernafaskan Islami) yang berjudul "Kisah Rasul " karya Ustadz Ilham Ilyas, yang menceritakan tentang perjalanan dan Jihad Rasululloh bersama sahabat saat hidup di Mekah.

\section{Analisis, Refleksi, dan Revisi Pembelajaran}

Berdasarkan hasil refleksi terhadap kegiatan pembelajaran dengan nasyid (lagulagu bernafaskan Islami) pada tindakan kedua tersebut menunjukkan bahwa kegiatan kerja kelompok yang telah dilakukan siswa dalam pembelajaran Agama Islam untuk pokok bahasan menyelesaikan adan memaknai cerita kisah rasul yang dapat meningkatkan kemampuan siswa dalam pemahaman tarekh (sejarah) Rasululoh. Hal tersebut tampak dari adanya perubahan hasil evaluasi masing-masing siswa setelah melaksanakan kerja kelompok sesuai dengan kemampuan yang dimiliki. Dengan demikian dapat disimpulkan bahwa secara umum kegiatan pembelajaran pada tindakan kedua ini telah sesuai dengan harapan penulis dalam melakukan tindakan kelas dengan menggunakan pendekatan menggunakan nasyid (lagu-lagu bernafaskan Islami) . 
Tabel

Nilai Tes Responden di siswa Pada Tahap II

\begin{tabular}{|c|c|c|c|c|c|c|}
\hline No & Nilai & No & Nilai & No & Nilai & Keterangan \\
\hline 1 & 8.4 & 12 & 8.5 & 23 & 7.5 & \multirow{11}{*}{ Batas lulus 7.0} \\
\hline 2 & 7.5 & 13 & 6.5 & 24 & 7.5 & \\
\hline 3 & 8.5 & 14 & 8.0 & 25 & 8.0 & \\
\hline 4 & 7.5 & 15 & 8.0 & 26 & 7.5 & \\
\hline 5 & 6.5 & 16 & 8.0 & 27 & 8.0 & \\
\hline 6 & 7.0 & 17 & 8.5 & 28 & 7.5 & \\
\hline 7 & 9.5 & 18 & 8.5 & 29 & 8.5 & \\
\hline 8 & 7.0 & 19 & 8.5 & 30 & 8.5 & \\
\hline 9 & 8.5 & 20 & 8.5 & 31 & 8.5 & \\
\hline 10 & 8.5 & 21 & 8.5 & 32 & 8.5 & \\
\hline 11 & 8.0 & 22 & 8.5 & & & \\
\hline
\end{tabular}

Dari tabel tersebut dapat disimpulkan bahwa pada tahap II ada 29 orang siswa dinyatakan lulus, sedangkan sisanya dinyatakan tidak lulus dalam pre tes. Sedangkan nilai rata-rata kelas dari pre tes tersebut adalah 8.13.

Pada kegiatan inti, guru menyajikan soal cerita kisah Rasul dan menginformasikan langkah-langkah yang harus dilakukan siswa pada saat menyelesaikan cerita secara klasikal. Kemudian guru menugaskan siswa masuk dalam kelompok yang telah dibentuk untuk melaksanakan tugas menyelesaikan LKS yang dibagikan guru. Dengan demikian nampaklah keberhasilan pengajaran agaa Islam dengan menggunakan model Pembelajaran Nasyid pada siswa SMA Negeri 1 Ambunten

Berdasarkan hasil pengamatan terhadap tindakan di atas menunjukkan bahwa kegiatan pembelajaran dengan menggunakan nasyid (lagu-lagu bernafaskan Islami) sesuai dengan yang diharapkan oleh peneliti.

Pada kegiatan penelitian tindakan kelas dengan menggunakan media Nasyid sebagai instrumen pengajaran Agama Islam pada siswa SMA Negeri 1 Ambunten, maka penulis merasa ada keberhasilan dalam melaksanakan kegiatan penelitian ilmiah tersebut 
dengan ditunjukkan tingkat keberhasilan siswa dalam menerima materi ajar Kisah perjalanan Rasululloh dengan hasil tes yang cukup memuaskan.

\section{Kesimpulan}

Kesimpulan yang dapat dirumuskan merupakan hasil akhir dari pengujian-pengujian hipotesis penelitian yang telah dilakukan. Kesimpulan yang diambil hanya relevan dan berlaku bagi populasi penelitian yaitu siswa SMA Negeri 1 Ambunten. Karena untuk setiap kelompok individu tertentu memiliki karakter dan sosial yang berbeda. Kesimpulan yang dapat diambil dari penelitian ini adalah:

1. Terdapat perbedaan perolehan belajar yang signifikan antara pembelajaran Agama Islam pokok bahasan kisah perjalanan Rasulullah dengan menggunakan nasyid (lagu-lagu bernafaskan Islami) pada siswa SMA Negeri 1 Ambunten, Artinya penggunaan.nasyid (lagu-lagu bernafaskan Islami) untuk menata lingkungan belajar dapat meningkatkan perolehan belajar. Belajar akan bermakna dan berhasil ketika pebelajar (siswa) terbebas dari tekanan dan ketegangan. Nasyid (lagu-lagu bernafaskan Islami) yang diperdengarkan dapat menentukan suasana hati pendengar dan pencintanya. Suara nasyid (lagu-lagu bernafaskan Islami) yang santai dengan irama yang tepat dapat menolong melepaskan semua bentuk ketegangan.

2. Terdapat interaksi yang nyata antara penggunaan nasyid (lagu-lagu bernafaskan Islami), gaya belajar dengan perolehan belajar siswa bagi siswa SMA Negeri 1 Ambunten. Hasil ini memberikan petunjuk bahwa antara nasyid (lagu-lagu bernafaskan Islami), gaya belajar dan hasil belajar mempunyai hubungan yang erat. Nasyid (lagu-lagu bernafaskan Islami) dan gaya belajar memiliki pengaruh secara signifikan dalam peningkatan perolehan belajar.

Proses belajar sangat dipengaruhi oleh lingkungan fisik. Misalnya cahaya, suhu, tempat duduk dan sikap tubuh, serta suara. Nasyid (lagu-lagu bernafaskan Islami) dalam hal ini merupakan salah satu faktor yang besar perannya dalam membangun proses belajar siswa. Sedang gaya belajar siswa akan membentuk pola bagaimana siswa menangkap dan mencerna informasi-informasi dan bagaimana siswa merekam dalam sistem memorinya. 


\section{Daftar Pustaka}

Azumardi Azra., 2003, Nasyid (lagu-lagu bernafaskan Islami) sebagai pembelajaran Agama Islam, UNISKA, Kediri..

Arikunto, Suharsimi, 1993, Manajemen Pengajaran Secara Manusiawi, Rineka Cipta, Jakarta.

Black, A. James., Champion, J.Dean, 2001, Metode dan Masalah Penelitian Sosial, Refika Aditama, Bandung.

Best, W. John., 1982, Metodologi Penelitian Pendidikan, alih bahasa : Sanapiah Faisal, Mulyadi Guntur W., Usaha Nasional, Surabaya.

Campbell, Don. 2001, Efek Mozart, Alih bahasa T. Hermaya, Gramedia Pustaka Utama, Jakarta.

De Porter, Bobbi., Reardon, Mark,. Singer, Sarah Nourie, 2000, Quantum Teaching, Terjemah : Ary Nilandari, Kaifa, Bandung.

De Porter, Bobbi., Hernacki, Mike., 2000, Quantum Learning, Terjemah Alwiyah Abdurrahman, Kaifa, Bandung.

Degeng, I Nyoman Sudana, 1989. Ilmu Pengajaran Taksonomi Variabel, Depdikbud Dirjen Dikti, Proyek Pengembangan Lembaga Pendidikan Tenaga Kependidikan, Jakarta.

Depag, 2001. Kisah-Kisah Para Ambiyaq, edisi kedua, Balai Pustaka, Jakarta.

Dryden, Gordon., Vos, Jeannette., 2001, The Learning Revolution, The Learning Web, Selandia Baru, Terjemahan Word + + Translation Service, Kaifa, Bandung.

Fajar, H.A. Malik, 2001, Platform Pendidikan dan Pengembangan Sunber Daya Manusia, Logos Wacana Ilmu, Jakarta.

Mader, S. Silvia, 1995, IPA, Keanekaragaman dan Lingkungan jilid 4, Alih bahasa Babby Sri Poernomo, Kucica, Jakarta.

Moleong, J.Lexy, 2000, Metodologi Penelitian Kualitatif, Remaja RoSMAakarya, Bandung.

Mukhadis, Amat., 1997, Instrumen Evaluasi Program Pembelajaran Dan Pelatihan : Jenis, Karakteristik dan Pengembangannya, Buku Penunjang Perkuliahan Penilaian Hasil Belajar, Fakultas Pendidikan Teknologi dan Kejuruan, IKIP Malang.

Mustaqim, 2001, Psikologi Pendidikan, Fakultas Tarbiyah IAIN Walisongo, Semarang. 